
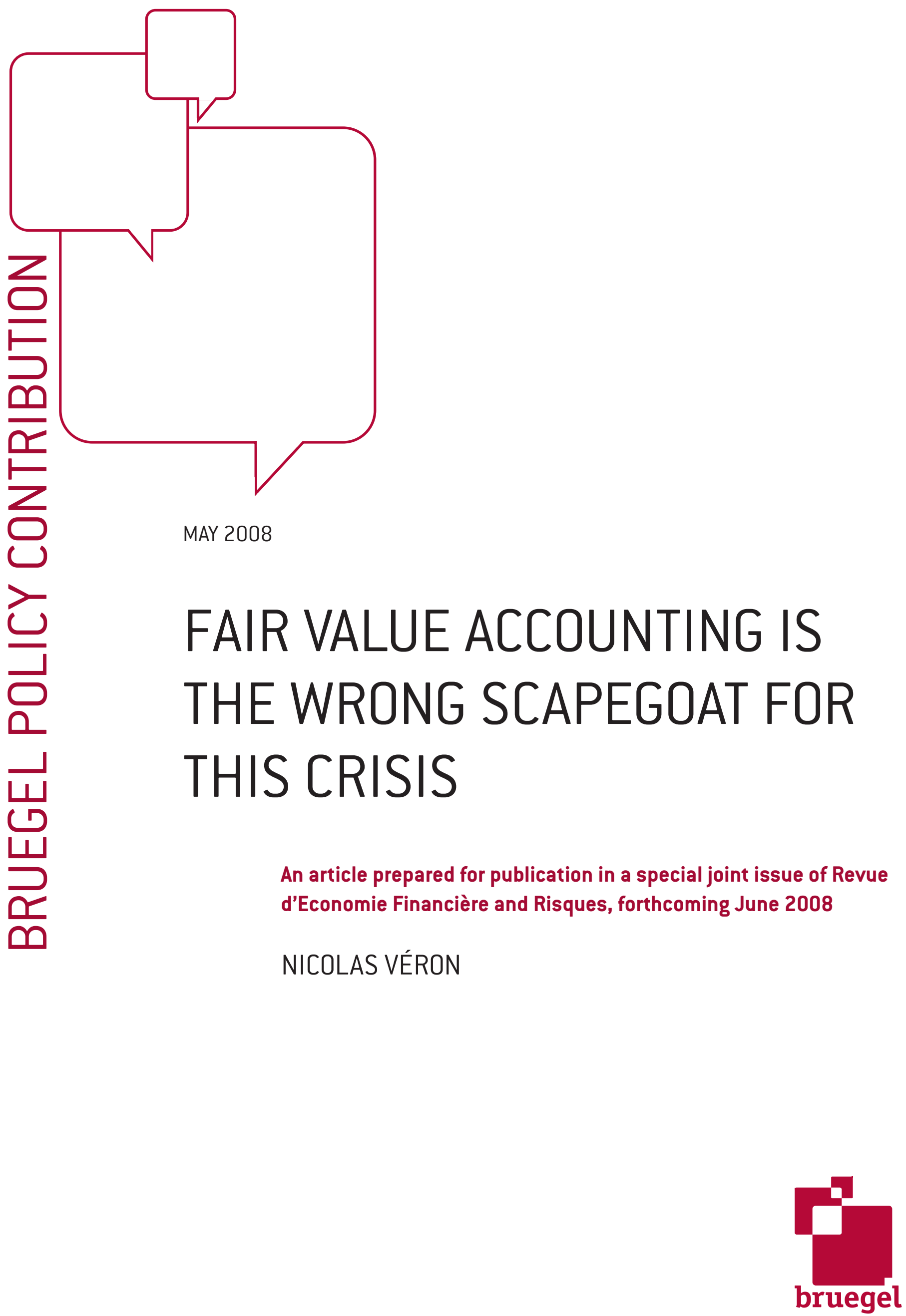


\title{
Fair Value Accounting Is the Wrong Scapegoat for This Crisis
}

\author{
Nicolas Véron
}

May 2008

An initial version of this text was prepared in French for publication in a special joint issue of Revue d'Economie Financière and Risques, forthcoming June 2008.

The ongoing financial crisis has spurred much finger-pointing at fair value accounting for financial instruments, as set out in both leading sets of accounting standards used by listed companies around the world, namely US Generally Accepted Accounting Principles (US GAAP) and International Financial Reporting Standards (IFRS). Prominent financial leaders such as Martin Sullivan, CEO of AIG, and Henri de Castries, CEO of AXA, have singled out fair value and the related wide use of mark-to-market accounting as a major factor in the crisis ${ }^{1}$. Echoing these views, European Commissioner Charlie McCreevy expressed his concern on 1 April this year about the 'impact of mark to market valuation when markets generally become illiquid and irrational'2.

On closer inspection, there is not just one criticism of fair value accounting, but two, centering respectively on illiquidity and procyclicality. The illiquidity criticism focuses on complex products resulting from securitisation of assets such as mortgage loans, which are at the core of the current financial crisis. Both IFRS and US GAAP define the fair value of financial instruments under a three-level framework: it is set as the observable market price of the instrument, or (absent the former) the observable market price of a similar item, or (if none of the previous two can be found) the result of a financial valuation model. The illiquidity criticism notes that market conditions of many complex financial instruments since last August are marked by an imbalance between supply and demand, which means that market prices are rendered abnormal by the evaporation of liquidity and may bear no relation to underlying value defined as the potential to generate future cash flows. Indications of price for instruments that may be considered 'similar' for accounting purposes (the second level in the fair value definition), such as the ABX indices published by the financial information firm Markit, have considerably dropped in value since August 2007, and trading volumes on the indices are themselves limited. Thus, the argument goes, fair value obliges banks to record a drop in value unjustified by economic fundamentals, with a corresponding reduction in shareholders' equity. To maintain their solvency ratios, they are then forced either to raise new capital under depressed valuation conditions to the detriment of existing shareholders, or to reduce lending with the risk of a depressive effect on the economy as a whole ${ }^{3}$.

The procyclicality criticism is much broader in scope. According to it, the very idea that market prices when observable provide the best possible indication of value is flawed, because it boosts the apparent robustness of banks' balance sheets at the top of the cycle and reduces it by the same measure at the bottom. The champions of this arguments frequently refer to economic research which has shown for decades that markets are often imperfect, even in normal times and all the more so in periods of speculative bubbles or of collective

\footnotetext{
${ }^{1}$ See Jennifer Hughes and Gillian Tett, ‘An unforgiving eye: Bankers cry foul over fair value accounting’, Financial Times, 14 March 2008.

2 Charlie McCreevy, testimony before the Economic and Monetary Affairs Committee of the European Parliament, 1 April 2008.

${ }^{3}$ See for example Paul De Grauwe, 'Act now to stop the markets' vicious circle', Financial Times, 20 March 2008.
} 
panic, especially because of information asymmetries and differences among market participants in terms of beliefs and behaviour. By granting too much relevance to markets, accounting standards would thus be culprits of accentuating both booms and busts. This criticism questions fair value accounting not only when applied to illiquid securities, but also in much more general terms as the guiding principle for accounting recognition of a broad range of financial instruments ${ }^{4}$.

The difficulties to which these criticisms refer are real enough. But the policy conclusion they draw, namely that current standards should be temporarily or permanently amended in order to restrict the scope of fair value accounting, remains unconvincing, for at least three reasons. It does not provide any credible alternatives to the standards currently in force. It disregards the negative impact which would result from the loss of data presently supplied by financial reporting in compliance with these standards. And it unhelpfully muddies the distinction between accounting and prudential concerns, which correspond to different objectives and should be more carefully distinguished.

Critics are at a loss to accompany their arguments with credible counter-proposals. While it is straightforward to pinpoint the faults inherent in fair value accounting, it is less easy to identify an alternative method which would better fulfill the features of relevance, reliability, comparability and understandability which a broad consensus, as well as formal statements of principles, assigns to financial accounting standards ${ }^{5}$. Reference to historical prices, which is sometimes mentioned in this debate, would provide less comparable and much less relevant information, and is clearly rejected by users of financial information, prominent among them financial investors. Reference to notional prices set by public authorities, which was the guiding accounting principle of the collectivised economies of pre-perestroïka Soviet Union and of pre-Deng-Xiaoping China, enjoy even lower credibility, at least among most economists and capital market participants. When there is a liquid and deep market, the idea that accounting entries could be consistently pegged above market prices runs contrary to prudence and does not brook scrutiny for long.

Illiquid financial instruments pose a trickier challenge, but even there, the idea of reducing the scope of fair value has not generated credible alternatives to current accounting standards, which themselves are hybrid in essence (many assets are outside the scope of fair value) and the fruit of decades of trials and errors. One option sometimes proposed is to replace the reference to 'similar' instruments, central to the present difficulties surrounding securitisation products, by an internal valuation model, or 'mark-to-model' (under fair value accounting, marking to model is allowed only when no market prices can be observed for similar instruments). Models are already widely used ${ }^{6}$, and they may aid transparency if backed up by detailed information about underlying instruments and assumptions. But they also generally provide management with considerable scope for determining the key parameters, such as the discount rate and future financial flows, and thus influencing the value the model may assign to a given instrument. Thus, the vast majority of investors see models as a solution of last resort, and tend to prefer market price references when such references exist. As Warren Buffett remarked as long as five years ago in a quip that has often been quoted since, 'in

\footnotetext{
${ }^{4}$ See for example Yves de Kerdrel, 'Les marches contre la démocratie' (Markets against Democracy), Le Figaro, 18 March 2008.

${ }^{5}$ These features are themselves not always mutually reinforcing, and the respective priorities assigned to them in accounting standards depends on the political economy in which standard-setting takes place. For a more indepth analysis, see Nicolas Véron, Matthieu Autret and Alfred Galichon, Smoke \& Mirrors, Inc.: Accounting for Capitalism, Cornell University Press, 2006.

${ }^{6}$ Goldman Sachs, for example, had \$96.4bn of assets marked to model ('level 3 assets' in US GAAP jargon) on its balance sheet as of end-February 2008. Yalman Onaran, 'Goldman Sachs Level 3 Assets Jump, Exceeding Rivals’’, Bloomberg wire service, 8 April 2008
} 
extreme cases, mark-to-model degenerates into what I would call mark-to-myth'7 . For investors, reference to an actual market transaction, even an imperfect one, is preferable in principle to an internal model elaborated by the issuer.

Other proposals have been tabled to cushion the accounting shock resulting from the market turmoil for financial firms, but none win the day. In a comment piece published on 3 April 2008 in the Financial Times, three members of the Technical Expert Group of the European Financial Reporting Advisory Group $\left(\mathrm{EFRAG}^{8}\right)$, all employees or former employees of large listed companies (Bear Stearns, BP and Siemens respectively), proposed a mechanism for smoothing market prices over a period of six months to one year to serve as a yardstick for writing down financial assets ${ }^{9}$. But this proposal, which would dampen the information content of financial statements by making them less responsive to market movements, would not necessarily help to achieve the objective sought by its authors. In the specific case which has focused debate, the use of the $\mathrm{ABX}$ indices as a price reference for mortgage-backed securities, it would arguably not have significantly improved the lot of banks. As of late April 2008, and in spite of a recent rebound, the value of these indices has remained depressed for more than six months, and an average over this period would still produce an 'artificially low' value compared with what critics of fair value deem 'economic fundamentals ${ }^{\text {, }}$.

While the alternatives to fair value do not throw up any obvious answers to the immediate needs, they do on the other hand have a potentially harmful feature in common. These proposals reduce the information available to investors and other users of financial information, and in many cases provide firms with tools to 'manage earnings' and to skew reporting in a way which fair value accounting, even hit by the drying up of liquidity, does not permit or at least not to the same degree. Thus, if such proposals were to be adopted, they would most likely entail a higher risk premium for shares generally, and weaker market performance. This effect was observed in spectacular fashion in 1990s Japan, when the ministry of finance allowed banks to avoid depreciating assets whose value had been reduced as a result of market depression. The upshot was an across-the-board loss of confidence in banks' financial reporting, which most observers today think helped to exacerbate the financial crisis rather than attenuate it.

Moreover, the fear associated with a possible overprovisioning of losses due to fair value accounting under unusual market conditions is at best only marginally based on empirical observation of market behaviour. Over the last few months, markets have on occasions shown remarkable resilience to the announcement of sometimes spectacular accounting losses on the part of banks. In a particularly noteworthy case, the disclosure by UBS of a \$19 billion writedown in the first quarter of 2008, on 1 April, led to an upsurge of around $15 \%$ in the share price compared with the closing price of the previous day, which was maintained over subsequent trading days. By contrast, episodes where the market abruptly lost confidence in a financial firm, for example in Bear Stearns on 13 and 14 March 2008, were not associated with new accounting disclosures but with more fundamental fears about intrinsic liquidity and solvency. In other words, markets do not appear to be blinded by 'artificial' features of accounting data. The problems encountered are real and relate to dysfunction of the market itself, rather than to the way in which the market is reported through accounting.

\footnotetext{
${ }^{7}$ Warren Buffett, Letter to shareholders, included in the annual report of Berkshire Hathaway Inc. for 2003.

${ }^{8}$ EFRAG is a private organisation consulted by the European Commission before taking its decisions on the adoption of the IFRS accounting standards.

${ }^{9}$ Carsten Zielke, Michael Starkie and Thomas Seeberg, 'Reporting move could break the writedown spiral', Financial Times, 3 April 2008

${ }^{10}$ The chairmen of EFRAG and of its Technical Expert Group publicly distanced themselves from the three experts' proposal: Göran Tidström and Stig Enevoldsen, 'No view formed on the credit crunch', Financial Times, 14 April 2008
} 
At the end of the day, fair value accounting as currently prescribed by IFRS and US GAAP standards can be described in analogy with Churchill's portrayal of democracy, as the worst system with the exception of all others ${ }^{11}$. Reference to 'similar items' such as the ABX indices is far from ideal in present circumstances, but this does not warrant a change in the standards, as no alternative standard would convincingly lead to better accounting in the current troubled market environment. However, this does not imply that the standards, whether IFRS or US GAAP, are perfect. They will certainly be subject to amendment in the years to come, as the chairman of the International Accounting Standards Board (the IFRS standards-setter) has himself recently suggested ${ }^{12}$. But the scope allotted to fair value and mark-to-market accounting does not seem excessive in light of the characteristics of financial markets in the developed world, and of lessons drawn from past crises. Restricting this scope would not cure the current ills of markets. On the contrary, it would risk making them worse, by reducing the level of confidence which investors and observers have in financial services companies’ published accounts.

Other changes are needed in order to meet the challenges thrown up by the current crisis, which indeed is to a significant extent a crisis of financial information. First, deficiencies of measurement under current market conditions must be corrected as far as possible by the provision of appropriate information in disclosure notes to the accounts. This would allow users to put the financial statements into perspective, in particular when they are shaped by scrambled market signals. In March 2008 the US Securities and Exchange Commission (SEC) clarified and reinforced these information requirements in a letter to all issuers of shares listed in the US ${ }^{13}$. Comparable recommendations were drawn up by the Financial Stability Forum (FSF) in its report tabled to G7 finance ministers in April 2008 ${ }^{14}$. The requirements of the IFRS standards on this aspect will probably be bolstered in the future, notwithstanding the progress already accomplished by the entry into force in 2007 of the IFRS 7 standard on disclosures about financial instruments.

Beyond the standards themselves, how they are applied is a key issue, whose importance is often underestimated in Europe. The quality and international consistency of IFRS implementation and enforcement is vital to financial stability, as the Banking supervision committee of the Eurosystem had stressed before the crisis began ${ }^{15}$. From this standpoint, the present situation in the European Union is a legitimate cause for concern, as was vividly illustrated by a controversy in March 2008 about the accounting policies chosen by Société Générale to book the loss caused by the trading activities of its former employee Jérôme Kerviel $^{16}$. The financial crisis might lead Europeans to revisit their current fragmented setting and to contemplate a more credible framework to monitor IFRS implementation, sanction improper practice, and provide relevant guidance. For Europeans, this would also go some way towards reducing the political risk which would emerge in case of dominant influence of the SEC Chief Accountant on global IFRS implementation doctrine ${ }^{17}$.

\footnotetext{
${ }^{11}$ See for example Pierre Cailleteau, ‘Archaeology of the Crisis', Moody’s Global Financial Risk Perspectives, January 2008, available at www.moodys.com

${ }^{12}$ David Tweedie, 'Simple solution clearly needed in a complex world', Financial Times, 20 March 2008.

${ }^{13}$ See for example Sarah Johnson, 'SEC Wants Firms to Explain Fair-Value Choices', CFO.com, 31 March 2008

${ }^{14}$ Financial Stability Forum, 'Report of the Financial Stability Forum on Enhancing Market and Institutional Resilience', 7 April 2008, available at www.fsforum.org

15 ESCB Banking Supervision Committee, 'Assessment of accounting standards from a financial stability perspective’, European Central Bank, December 2006

${ }^{16}$ See Jennifer Hughes, 'SocGen uses accounting override to book Kerviel losses in 2007' and 'Override that is dividing accountants’, Financial Times, 11 and 12 March 2008

${ }^{17}$ A proposal to create a European chief accountant is developed in Nicolas Véron, 'The Global Accounting Experiment', Bruegel Blueprint series, April 2007.
} 
Moreover, accounting information, including all disclosures mandated by the standards, is only one part of the financial information supplied by financial services companies. As the FSF also rightly pointed out in its April 2008 report, transparency regarding financial risks needs to be much improved compared to its current level, in particular in light of the lessons of the financial crisis and the reduction in the relative importance assigned to credit ratings. Improving financial risk disclosures is a potentially decisive factor in shoring up the financial stability regime ${ }^{18}$. It should be contemplated not only for the regulated banking industry, but also for non-regulated financial players more broadly ${ }^{19}$.

Last but not least, a sharper distinction must be made than has been the case until now between the requirements of financial accounting, as they apply to listed companies in particular, and the prudential requirements imposed by supervisors on financial firms. The accounting measure of shareholders' equity is simply not the best way to track bank capital for prudential purposes. As we have argued, the pro-cyclical effect of fair value accounting does not impair its relevance for the purposes of investors, who need a measure of a company's financial position at a given point of time under that moment's market conditions. However, it would make sense to correct certain multi-year-cycle effects when financial information is analysed in a prudential framework. From this point of view, the Basel II accord bears weaknesses when tested in the current financial crisis, and is likely to be revised in the coming years. The already mentioned FSF report and the corresponding statement of G7 finance ministers and central bankers on 11 April 2008 are evidence that this distinction between accounting and prudential considerations, often neglected in the recent past, may henceforth be properly heeded by public authorities.

A vigorous debate about fair value is made necessary by the current financial disruption, which provides a real-world litmus test of accounting standards. This test has not yet provided any reason to revert the choice made in 2000-02 by the European Union to adopt international accounting standards designed primarily to meet the financial information needs of investors, including the scope of fair value accounting as it is currently defined by IFRS. Even in the extraordinary circumstances which have prevailed on financial markets since August 2007, breaking or tweaking the financial accounting thermometer would not improve the health of the patient, and would only make the doctors' task that bit harder.

\footnotetext{
18 See Claudio Borio and Kostas Tsatsaronis, 'Accounting, Prudential Regulation and Financial Stability: Elements of a Synthesis’, Working Paper ${ }^{\circ} 180$ of the Bank for International Settlements, September 2005; and the revealing study carried out for the FSF by the 'Senior Supervisors' Group' which brings together eight European and US supervisory authorities, 'Leading-Practice Disclosures for Selected Exposures’, 11 April 2008, available at www.newyorkfed.org.

19 See for example Olivier Le Marois, 'How to detect hedge funds tricking investors', Financial Times, 1 April 2008.
} 